\title{
Removal of chromium (VI) from aqueous solution by natural clay
}

\author{
Yousif Algamal \\ Department of Chemistry, Faculty of Science \& Arts, Khullais, \\ University of Jeddah, Jeddah, KSA \\ Department of Chemistry, Faculty of Science \& Technology, \\ Omdurman Islamic University, Sudan. \\ N. M. Khalil \\ Department of Chemistry, Faculty of Science \& Arts, Khullais, \\ University of Jeddah, Jeddah, KSA \\ Refractories, Ceramics and Building Materials Department, \\ Nat. Res. Center, 12311 Cairo, Egypt \\ Qyied Saleem \\ Department of Chemistry, Faculty of Science \& Arts, Khullais, \\ University of Jeddah, Jeddah, KSA \\ Mohamed J. Almughrabi \\ Rabigh Power Plant, Rabigh, Saudi Arabia
}

\begin{abstract}
The adsorption of chromium (VI) from aqueous solution was carried out using natural clay from western area in Saudi Arabia. The adsorbents used are characterized by X-ray diffraction (XRD) and other physico-chemical techniques. The various parameters affecting the adsorption process were investigated involving effect of initial concentration of $\mathrm{Cr}$ (VI) ion, temperature factor, dosage of adsorbent, $\mathrm{pH}$ of the solution, contact time and rotational per minute (RPM). Optimum conditions for adsorption process were; $50 \mathrm{mg} / \mathrm{L}^{-1}$ initial concentration of $\operatorname{Cr}(\mathrm{VI})$, adsorbent dose $=1 \mathrm{~g}$, temperature $\sim 25^{\circ} \mathrm{C}, 3$ hours contact time and $\mathrm{pH}=2$, the obtained results were used to calculate the adsorption efficiency. Removal of chromium ion was found as highly depends on $\mathrm{pH}$ and initial $\mathrm{Cr}$ (VI) concentration of the solution. Langmuir isotherm was applied to get a maximum adsorption capacity of $18.68 \mathrm{mg} / \mathrm{g}$. Although experimental data confirm with Langmuir isotherm model. The results of this study confirm that the material can be considered as effective adsorbents for the removal of chromium (VI).
\end{abstract}

Keywords: Natural clay; Adsorption; Chromium (VI); Isotherm; XRD.

\section{INTRODUCTION}

Recently the major problem for the researchers that related to our environment is the pollution whatever its kind, the disposal of the metal ions which becoming a harmful and causing a sever problems. Some of these metal ions are essential to our living but an increase in their quantities make trouble and affecting the resources. Among these ions is the chromium ion, which exists naturally as in natural mineral (rocks, soil) and in living system (animals and plants). Chromium (III) plays important role in biological activity using sugar, protein, and fat required by our body whereas $\mathrm{Cr}$ (VI) is a toxic one usually used as a mixture with copper and arsenic in manufacturing the pesticides commonly known as CCA (Chromated copper arsenate) [1]. Chromium (VI) causing a cancer to human by eating or breathing [2]. It can be deposited in soil and easily compounded with other particles resulting in different oxidizing states [3]. Authors reported another source of chromium (VI) that comes from water industries 
(plastic containers and water pipes), tanning industries as well as electroplating process [3, 4]. Several methods like adsorption, ion exchange, membrane filtration and reverse osmosis were applied to remove $\mathrm{Cr}(\mathrm{VI})$ from industrial wastewater [4-6]. Adsorption process is commonly used to remove $\mathrm{Cr}(\mathrm{VI})$ from polluted water using different materials as adsorbent like charcoal, activated charcoal and activated aluminum [7], bentonite [4], wool [8], .... etc [9-11]. This study will focus on the adsorption of chromium (VI) from aqueous solution using natural clay collected from Khullais area in Kingdom of Saudi Arabia.

\section{EXPERIMENTAL SECTION}

\section{Reagents:}

Analar grades of $\mathrm{K}_{2} \mathrm{Cr}_{2} \mathrm{O}_{7}, \mathrm{HCl}, \mathrm{NaOH}$ were used. From these reagents, Stock solutions were prepared using double distilled water throughout the experiments. $(500 \mathrm{mg} / \mathrm{L}$ using $1.414 \mathrm{~g}$ in $1000 \mathrm{ml}$ of DD),1M of Hydrochloric acid and $1 \mathrm{M}$ of sodium hydroxide to adjust the $\mathrm{pH}$ values). The natural clay used was collected from Khullais area $90 \mathrm{~km}$ north Jeddah city, KSA. The chemical composition of the clay was checked using XRD technique.

\section{Equipment:}

$\mathrm{XRF}$ of the raw clay samples was testing using Philips X-ray fluorescence (XRF) machine while XRD was testing using D8 Advance Bruker Germany, Shaker Model GFL 3017 was used for shaking, $\mathrm{pH}$ meter (HANNA instruments) for measuring the $\mathrm{pH}$ values and UV-visible spectrophotometer (DR 5000, Hach, USA) also used. Atomic Absorption Spectrometry (AAS) (AA- 6200 Shimadzu) used to determine the total chromium concentration in the solution without botheration of its oxidation state of the metal [12]. The chromium hexavalent can be determined spectrophotometrically (Shimadzu (UV-1601), according to diphenyl carbazidebased method [13].

\section{Methods:}

The following adsorption processes were conducted, different concentration of $\mathrm{Cr}$ (VI) ions, varying the $\mathrm{pH}$ values, different $\mathrm{RPM}$, different contact time, different amount of adsorbent and different range of temperature to study the equilibrium state. A $250 \mathrm{ml}$ of $\mathrm{Cr}$ (VI) solution was transferred into a $500 \mathrm{ml}$ conical flask and addition with the $\mathrm{HCl} / \mathrm{NaOH}$ solution to adjust the desired $\mathrm{pH}$ value. To this solution, $1 \mathrm{~g}$ of natural clay was added then shaken at $200 \mathrm{RPM}$ for three hours. Flask well sealed and kept aside to decrease atmospheric loss. Then the solution was analyzed for chromium (VI) ions concentration after 24 hours. The $\mathrm{Cr}$ (VI) ions adsorbed on the surface of the adsorbent ' $Q$ ' was calculated using “Equation 1" as given below:

$$
Q=\frac{(C 0-C) V}{W}
$$

Where, ' $\mathrm{C}_{0}$ ' represents initial concentration of $\mathrm{Cr}(\mathrm{VI})(\mathrm{mg} / \mathrm{L})$ and ' $\mathrm{C}$ ' the concentration of $\mathrm{Cr}$ (VI) at different interval time ' $\mathrm{t}$ ', ' $\mathrm{V}$ ' represents the total volume taken in the conical flask and ' $W$ ' represents the amount of the adsorbent used. At equilibrium state ' $\mathrm{C}$ ' becomes ' $\mathrm{Ce}$ ' and ' $\mathrm{Q}$ ' becomes 'Qe'.

A $100 \mathrm{ml}$ of the stock solution of $\mathrm{Cr}(\mathrm{VI})$ ions $\left(50 \mathrm{mg} \mathrm{L}^{-1}\right)$ was placed in $250 \mathrm{~mL}$ flask. Enough amount of $1 \mathrm{M} \mathrm{HCl}$ solution is added to adjust the $\mathrm{pH}$ value at $\sim 2,1 \mathrm{~g}$ of the adsorbent (natural clay) was added to the solution, and then shaken at 200 RPM for a period of 3 hours at constant temperature $25.0 \pm 0.2{ }^{\circ} \mathrm{C}$. At different interval times, samples were collected and analyzed during the adsorption process to attain the equilibrium state. The percentage removal of chromium (VI) ions was calculated using "Equation 2". A duplicate run was done for checking 
the adsorption of chromium ions on the surface of the conical flask in the absence of natural clay. This experiment showed no notable adsorption by the conical flask surface.

$$
\operatorname{Cr}(V I) \text { removal } \%=\frac{100(C 0-C)}{C 0}
$$

Evaluation of various parameters on the adsorption process was conducted involving; different chromium (VI) solutions (20, 30, 40, 50, 100, 150, and $200 \mathrm{mg} \mathrm{L}^{-1}$ ), different temperatures from $25^{\circ} \mathrm{C}$ to $40^{\circ} \mathrm{C}$, pH range of 2.0 to 10.0 , RPM from 30 to $200 \mathrm{RPM}$, contact time in the range of 30 minutes to three hours, amount of adsorbent ranging from 0.5 to $3.5 \mathrm{~g}$.

Langmuir adsorption isotherm "Equation 3", can be applied to account for the equilibrium relationships between adsorbent and adsorbate [14].

$$
\frac{C e}{Q e}=\frac{1}{k Q \max }+\frac{C e}{Q \max }
$$

Where ' $\mathrm{C} e$ '; the $\mathrm{Cr}(\mathrm{VI})$ concentration (in $\mathrm{mgL}^{-1}$ ) at equilibrium state, ' $\mathrm{Q} e$ '; mass (in $\mathrm{mg} / \mathrm{g}$ ) of the adsorbed $\mathrm{Cr}(\mathrm{VI})$ ions at equilibrium state ' $k$ '; is the Langmuir constant ( $\mathrm{Lmg}^{-1}$ ), and ' $Q_{\max }$ '; the maximum value of adsorbed $\mathrm{Cr}(\mathrm{VI})$ ions (in $\mathrm{mg} / \mathrm{g}$ ). Thus, these constants relate the maximum adsorption capacity and the energy of adsorption.

\section{Characteristics of the adsorbents (Natural clay):}

\section{RESULTS AND DISCUSSION}

Chemical analysis of the raw clay sample is given in "Table 1". The table indicates that the used raw clay composed mainly of $\mathrm{SiO}_{2}, \mathrm{Al}_{2} \mathrm{O}_{3}$ and $\mathrm{Fe}_{2} \mathrm{O}_{3}$ with considerable contents of $\mathrm{Na} 2 \mathrm{O}$ and $\mathrm{CaO}$. The loss of ignition was $12.03 \%$, which corresponds to the evaporation of physical and chemical combined water together with the decomposed organic matter.

Table 1. Chemical composition of the natural clay

\begin{tabular}{|c|c|c|c|c|c|c|}
\hline Chemical composition & $\mathrm{SiO}_{2}$ & $\mathrm{Al}_{2} \mathrm{O}_{3}$ & $\mathrm{Fe}_{2} \mathrm{O}_{3}$ & $\mathrm{Na}_{2} \mathrm{O}$ & $\mathrm{CaO}$ & LOI \\
\hline Weight \% & 58.10 & 13.11 & 9.60 & 5.11 & 2.05 & 12.03 \\
\hline
\end{tabular}

"Figure 1" shows the mineral constituents of natural clay. The figure indicates that the clay sample contains quartz, nontronite in addition to some kaolinite and cronstedtite minerals.

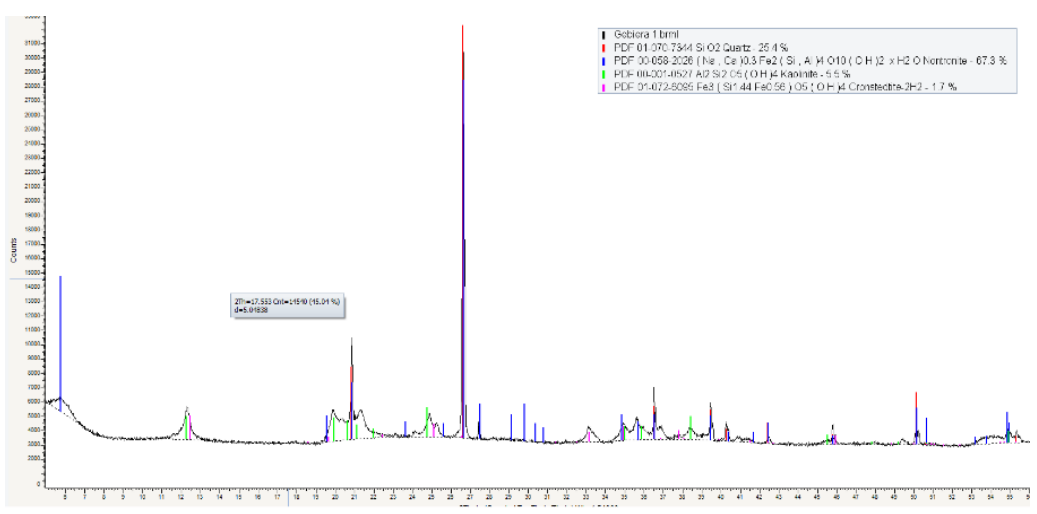

Figure 1. X-ray diffraction patterns of the natural clay

\section{Effect of $\mathrm{pH}$ of the solution}

"Figure 2", illustrates the effect of $\mathrm{pH}$ of the solution ranging from 2 to 10 on the removal of 
total $\mathrm{Cr}(\mathrm{VI})$ ions from the solution (keeping other parameters constant i.e., initial concentration of $\mathrm{Cr}(\mathrm{VI})$, temperature $25^{\circ} \mathrm{C}, \mathrm{RPM}=180$, time is 3 hours and using $1 \mathrm{~g}$ of clay. The maximum adsorption $(75 \%)$ on natural clay was obtained at $\mathrm{pH}=2.0$. It is a notable from the figure different removal percentage corresponds to different $\mathrm{pH}$ values $\mathrm{pH}$ ranging from 2 to 4 the removal percentage ranging from (75 to 60\%), $\mathrm{pH}$ ranging from 4 to 8 the removal is in the range of $(60-50 \%)$ and $\mathrm{pH}=8$ to 10 the removal is (50 to 40\%). This can be explained based on the possibility of formation of $\mathrm{Cr}(\mathrm{VI})$ anions in form of $\mathrm{HCrO}_{4}{ }^{-}, \mathrm{CrO}_{4}{ }^{2-}$, and $\mathrm{Cr}_{2} \mathrm{O}_{7}{ }^{2-}$, this can be explained in terms of chromium ions will have different states at different $\mathrm{pH}$ values [15] resulting in different charge density and easily can be bonded with the positively charged natural clay surface $[14,16]$. In addition, the lower efficiency $(50 \%)$ of the adsorbent at high $\mathrm{pH}$ values, the anions undergo transformation into diverse oxidation states. The reduction of chromium (VI) to chromium (III) was studied spectrophotometrically using the natural clay at different $\mathrm{pH}$ values, with $50 \mathrm{mg} / \mathrm{L}$ initial concentration of $\mathrm{Cr}(\mathrm{VI})$ solution [13].

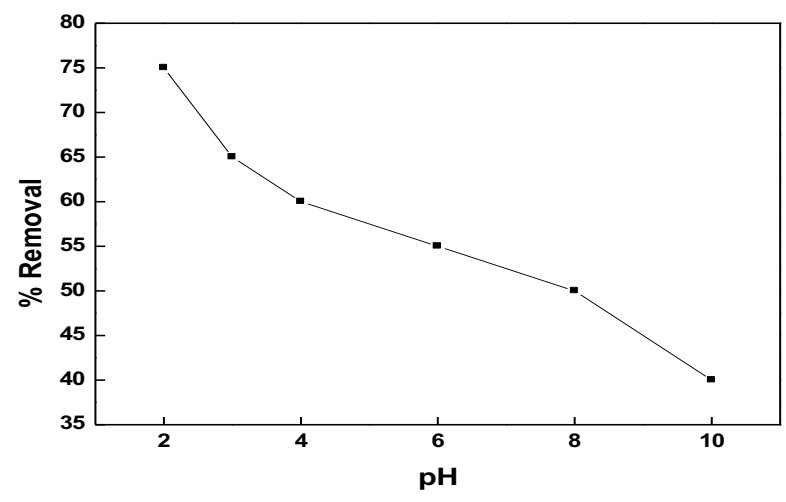

Figure 2. Effect of pH on $\mathrm{Cr}(\mathrm{VI})$ removal.

\section{Effect of $\mathrm{Cr}(\mathrm{VI})$ concentration:}

The efficiency percentage of $\mathrm{Cr}(\mathrm{VI})$ removal carried out at different concentrations of $\mathrm{Cr}(\mathrm{VI})$ ions varying from 50 to $200 \mathrm{mg} / \mathrm{L}$, keeping remaining factors constant (1 gm of natural clay, $\mathrm{pH}=2, \mathrm{RPM}=180$ and contact time of 3 hours) is shown in "Figure 3". The removal efficiency is increased with increasing the initial concentration of $\mathrm{Cr}(\mathrm{VI})$ up to $150 \mathrm{mgL}^{-1}$. For concentration higher than $150 \mathrm{mg} \mathrm{L}^{-1}$, the retention curves of total chromium and $\mathrm{Cr}(\mathrm{VI})$ start to advance further, suggesting chromium can have different oxidation state in these conditions. Assuming that the reduction of $\mathrm{Cr}(\mathrm{VI})$ to $\mathrm{Cr}(\mathrm{III})$ takes place on the natural clay and then releasing of the reduced form of chromium (III) leading to a curve retention. Same trend was reported with different adsorbents [17-23].

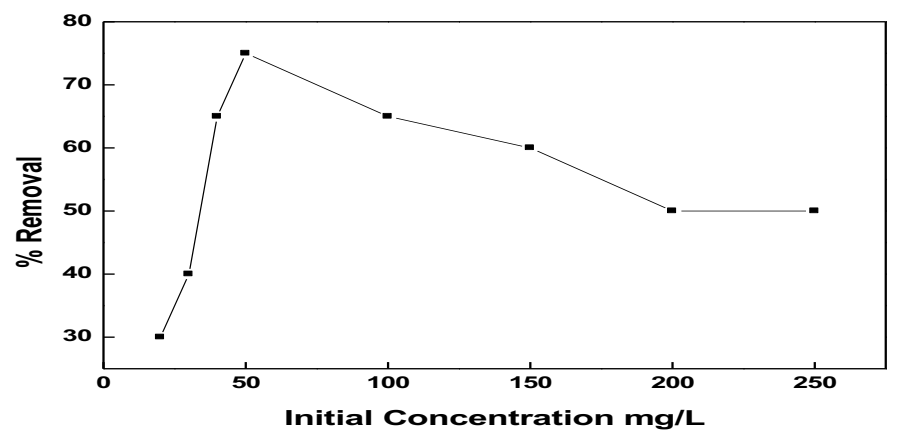

Figure 3. Effect of initial concentration on Cr(VI) removal. 


\section{Effect of adsorbent dosage:}

The percentage removal of chromium ions with different amount of adsorbents ranging from 0.5 to $3.5 \mathrm{~g}$ of natural clay keeping remaining factors constant $\left(50 \mathrm{mgL}^{-1}\right.$ of $\mathrm{Cr}(\mathrm{VI}), \mathrm{pH}=2, \mathrm{RPM}$ $=180$ and contact time of 3 hours) is shown in "Figure 4". The figure shows an increase of percentage removal of $\mathrm{Cr}$ (VI) when amount of adsorbent increased. From the figure, three stages in the curve could be recognized, the first increase ranging from 0.5 to $1 \mathrm{~g}$, the second increase in the curve correspond to $1.0-3.0 \mathrm{~g}$ and the third stage in the curve for the amount 3.0 to $4.0 \mathrm{~g}$ of adsorbent. This behavior is correlated with the chemical and mineralogical composition of the used clay i.e., the presence of $\mathrm{SiO}_{2}, \mathrm{Al}_{2} \mathrm{O}_{3}, \mathrm{Fe}_{2} \mathrm{O}_{3}, \mathrm{Na}_{2} \mathrm{O}$ and $\mathrm{CaO}$ in the form of quartz, nontronite, kaolinite and cronstedtite minerals which are known with the high adsorption capability [24,25]. As a result, the large amount of adsorbent (natural clay) enhances the uptake capacity of the adsorbent, and hence the metal ions can be easily occupying the active sites of the natural clay.

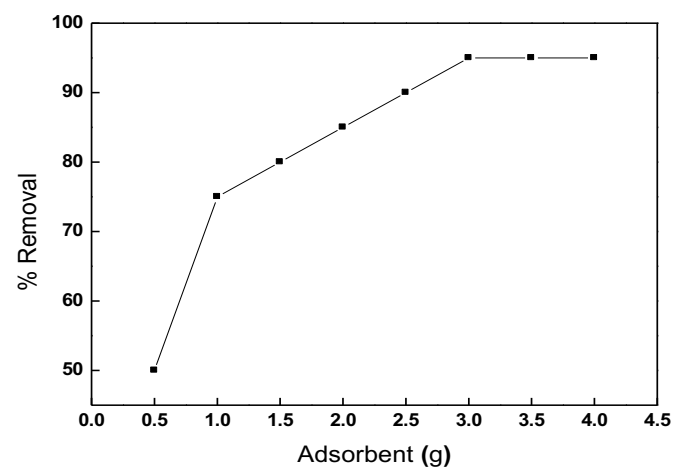

Figure 4. Effect of adsorbent dosage on $\operatorname{Cr}(\mathrm{VI})$ removal.

\section{Effect of contact time:}

The contact time plays an importance role in the adsorption process, keeping other parameters constants. "Figure 5", shows the percentage removal of $\mathrm{Cr}$ (VI) and the effect of contact time, the efficiency of removal of $\mathrm{Cr}(\mathrm{VI})$ increases with increasing the contact time, approximately $70-80 \%$ of maximum removal of $\mathrm{Cr}$ (VI) is attained within 210 minutes and the maximum adsorption is attained in 180 minutes. This can be explained based on the presence of the positively charged surface of the adsorbent for anionic Cr (VI) species present in the solution. The retention in the curve may be explained in sense of the electrostatic hindrance caused by already adsorbed negatively charged Cr (VI) ions in the solution [26].

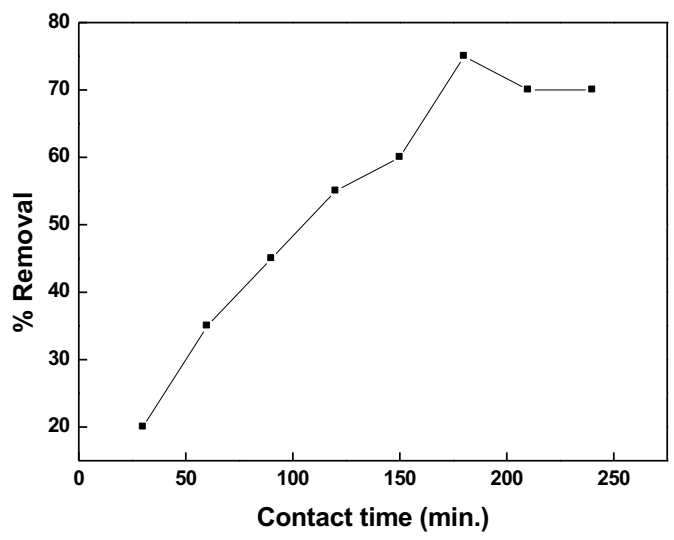

Figure 5. Effect of contact time on $\mathrm{Cr}$ (VI) removal. 


\section{Effect of temperature:}

Temperature play also an important role on the process of adsorption. A range of $25^{\circ} \mathrm{C}$ to $40^{\circ} \mathrm{C}$ temperature were studied keeping other parameters like initial concentration, $\mathrm{pH}, \mathrm{RPM}$ and adsorbent are constant. The obtained results show a decrease in percentage of adsorption with rise in temperature. This can be explained in terms of the desorption caused by the thermal energy. Thus, higher temperature results in higher mobility of the adsorbate causing desorption [27].

\section{Effect of RPM:}

The effect of RPM on the adsorption process was studied at different range 10 to 200 RPM keeping remaining parameters constant. "Figure 6", reveals an increase in the percentage of $\mathrm{Cr}$ (VI) removal with increase in RPM up to 180 , so it has been taken as the optimum rotational per minute for this study.

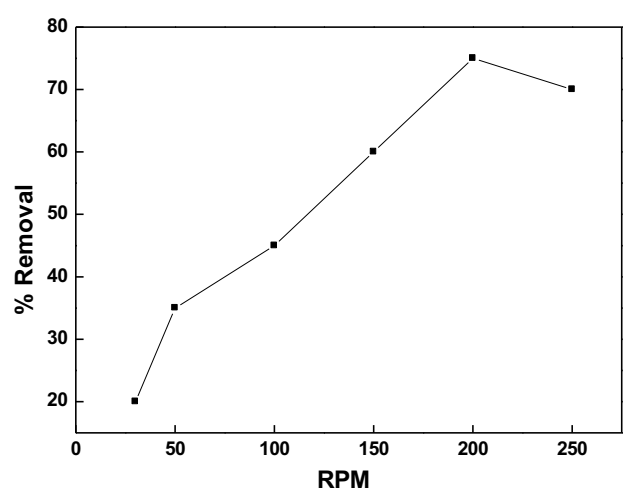

Figure 6. Effect of RPM on Cr (VI) removal.

\section{Adsorption isotherm:}

To determine the adsorption capacity, the Langmuir isotherm was applied, the isotherm also helping in modeling the equilibrium data equation (3). The experiment carried out at $\mathrm{pH}=2$. The points are fitted straightly "Figure 7", from a plot $C e / \mathrm{Q} e$ versus $C e$ the values of 'Qmax' and ' $\mathrm{k}$ ' are calculated (Langmuir constants) and their values are found to be 18.68 and 0.1265 respectively. The high value of correlation coefficient $\left(R^{2}=0.9857\right)$ indicates a good agreement with the parameters and confirms the monolayer adsorption of $\mathrm{Cr}(\mathrm{VI})$ onto the adsorbent surface. The importance of this isotherm supporting the feasibility of the natural clay as an efficient adsorbent in removing the chromium (VI) from aqueous solution.

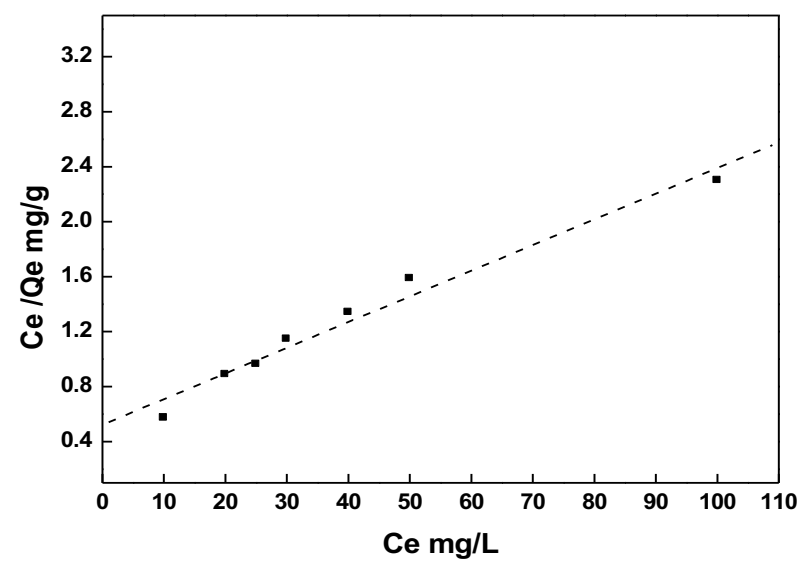

Figure 7. Langmuir isotherm for adsorption of $\operatorname{Cr}(\mathrm{VI})$ at $25^{\circ} \mathrm{C}$. 


\section{CONCLUSIONS}

From this study we can conclude that the natural clay collected from Khullais area in Kingdom of Saudi Arabia which is widely available, low cost and an effective adsorbent for $\mathrm{Cr}(\mathrm{VI})$ removal from aqueous solution at ambient $\mathrm{pH}$ since this material showed a relatively large capability of adsorption of chromium(VI) from aqueous solution. The following results were obtained:

- As $\mathrm{pH}$ increases \% removal of $\mathrm{Cr}(\mathrm{VI})$ decreases and the maximum \% removal of $\mathrm{Cr}(\mathrm{VI})$ at $\mathrm{pH}=2$

- As the contact time of adsorption increases the \% removal also increases, and the optimum time is $180 \mathrm{~min}$.

- As the amount of adsorbent increases, the \% removal of $\mathrm{Cr}$ (VI) is also increases.

- As the temperature increases the \% removal gets decreases.

- As the RPM increases the percentage removal gets increases and observed that the maximum \% removal at 200 RPM.

\section{References}

National Pesticide Information Center (NPIC), “Cooperative agreement between Oregon State University and the U.S. Environmental Protection Agency," 2011,

http://npic.orst.edu/ingred/ptype/treatwood/cca.html,http://npic.orst.edu/ingred/

ptype/treatwood/chromium.html.

Agency for toxic substances and disease registry (ATSDR). Toxicological Profile for Chromium: U.S Department of Health and Human Services, Atlanta. Ga, USA. 1998.

S. Katz, H. Salam.The Biological and Environmental Chemistry of Chromium: VCH Published, New York, NY, USA. 1994.

L. N. Shi, X. Zhang, Z. L. Chen. Removal of Chromium (VI) from wastewater using bentonite-supported nanoscale zero valent iron. Water Research. 45(2011)886-892.

Y. Zhao, S.Yang, D. Ding, J.Chen, Y. Yang, Z. Lei. Effective adsorption of Cr (VI) from aqueous solution using natural Akadama clay. Journal of Colloid and Interface Science. 395 (2013)198-204.

M. Khamis, F. Jumean, N. Abdo. Speciation and removal of chromium from aqueous solution by white, yellow and red UAE sand, Journal of Hazardous Materials.169 (2009)948-952.

S. Mor, K. Ravindra, N. R. Bishnoi. Adsorption of chromium from aqueous solution by activated alumina and activated charcoal, Bioresource Technology.98 (4), (2007) 954-957.

A. Manassra, M. Khamis, T. Ihmied, M. Eldakiky. Removal of chromium by continuous flow using wool packed columns. Electronic Journal of Environmental, Agricultural and Food Chemistry. 9(3), (2010) 651-663.

N. Daneshvar, D. Salari, S. Aber. Chromium adsorption and Cr (VI) reduction to trivalent chromium in aqueous solutions by soya cake. Journal of Hazardous Materials. 94(1), (2002) 49-61.

C. Modrogan, C. Costache, D. Orbulet. Removal of hexavalent chromium from aqueous solutions by adsorption on peach kernel and nutshell, in Proceedings of the 1st International Proficiency Testing Conference, Sinia, Romania 2007.

G. Rytwo Y. Gonen. Functionalized activated carbons for the removal of inorganic pollutants. Desalination and Water Treatment. 11(1-3),(2009) 318-323.

Determination of hexavalent and total chromium in effluent samples from electrolytic chrome plating operations, Bay Area Air Quality Management District, San Francisco, CA, Method 34 (Adopted 1/18/89, Reformatted 8/8/91) http://www.baaqmd.gov/ /media/Files/Records/MOP/vol\%203/MOP-34.ashx? la=en.

Chromium hexavalent (colorimetric), EPA Method 7196A1992,

http://www.epa.gov/osw/hazard/testmethods/sw-846/pdfs/7196a.pdf.

M. Dakiky, M. Khamis, A. Manassra, M. Mer'eb. Selective adsorption of chromium (VI) in industrial wastewater using low-cost abundantly available adsorbents. Advances in Environmental Research.6 (4), (2002)533-540.

L.A. Rodrigues, L.J. Maschio, R. E. da Silva, M.L.C.P.da Silva. Adsorption of Cr(VI) from aqueous solution by hydrous zirconium oxide. J. Hazard Mater.173 (2010) 630-636. 
B. M. Weckhuysen, I. E. Wachs, R. A. Schoonheydt. Surface chemistry and spectroscopy of chromium in inorganic oxides. Chemical Reviews. 96(8), (1996) 3327-3349.

M. Rao, A. V. Parwate, A. G. Bhole. Removal of $\mathrm{Cr}^{6+}$ and $\mathrm{Ni}^{2+}$ from aqueous solution using bagasse and fly ash. Waste Management. 22(7), (2002) 821-830.

M. R. Unnithan T. S. Anirudhan. The kinetics and thermodynamics of sorption of chromium (VI) onto the iron(III) complex of a carboxylated polyacrylamide-grafted sawdust. Industrial and Engineering Chemistry Research. 40(12), (2001)2693-2701.

C. Raji T. S. Anirudhan. Batch Cr(VI) removal by polyacrylamide-grafted sawdust: kinetics and thermodynamics. Water Research. 32(12), (1998)3772-3780.

J. Wu, H. Zhang, P.-J. He, Q. Yao, L.-M. Shao. Cr (VI) removal from aqueous solution by dried activated sludge biomass. Journal of Hazardous Materials.176 (1-3), (2010) 697-703.

P. Yuan, D. Liu, M. Fan et al. Removal of hexavalent chromium [Cr(VI)] from aqueous solutions by the diatomite supported/unsupported magnetite nanoparticles, Journal of Hazardous Materials.173(1-3), (2010) 614-621.

X. S. Wang, L. F. Chen, F. Y. Li, K. L. Chen, W. Y. Wan, Y.J. Tang. Removal of Cr (VI) with wheat-residue derived black carbon: reaction mechanism and adsorption performance. Journal of Hazardous Materials.175 (1-3), (2010) 816822 .

S. S. Liu, Y. Z. Chen, L. De Zhang et al., Enhanced removal of trace Cr(VI) ions from aqueous solution by titanium oxide-Ag composite adsorbents, Journal of Hazardous Materials. 190 (1-3), (2011) 723-728.

R. Lahkale, R. Sadik, E. Sabbar. Removal of trivalent chromium from tannery effluent by calcined layered double hydroxide. J. Mater. Environ. Sci. 5(2014)2403-.

J. Hmimou, E.H. Rifi, A. Lebkiri, L. Chafki, M.E. Touhami, Z. Hatim. Removal of Heavy Metals from Aqueous by Thephosphate Dihydrate Dicalcium. Mor. J. Chem. 3(2015) 74-.

U.C. Ghosh, S. Goswami. Studies on adsorption behavior of Cr (VI) onto synthetic hydrous stannic oxide. Water SA. 31(4), (2005)597-602.

G.F. Froment, K.B. Bischoff. Chemical Reactor Analysis and Design. Second Ed., John Wiley, Singapore. 1990. 